\title{
Ocular Affection as an Extraintestinal Manifestation in Cases of Inflammatory Bowel Disease at the Kafrelsheikh Governorate
}

\section{Afecção ocular como manifestação extraintestinal em casos de doença inflamatória intestinal}

\author{
Mohammed Hussien Ahmed ${ }^{10}$ Mohammed Elashery ${ }^{2}$ Hebatallah Abdel Maksoud ${ }^{3}$ (1)
}

Aya Mohammed Mahros ${ }^{10}$

${ }^{1}$ Department of Hepatology, Gastroenterology and Infectious

Address for correspondence Aya Mohammed Mahros, MD, Diseases, Faculty of Medicine, Kafrelsheikh University, Kafr Al Sheikh First, Kafr El Sheikh Governorate, Egypt

2 Department of Ophthalmology, Faculty of Medicine, Kafrelsheikh Department of Hepatology, Gastroenterology and Infectious Diseases, Faculty of Medicine, Kafrelsheikh University, Kafr Al Sheikh First, Kafr El Sheikh Governorate, Egypt University, Kafr Al Sheikh First, Kafr El Sheikh Governorate, Egypt (e-mail: yoye_85@hotmail.com).

${ }^{3}$ Department of Community Medicine, Faculty of Medicine, Kafrelsheikh University, Kafr Al Sheikh First, Kafr El Sheikh

Governorate, Egypt

J Coloproctol 2021;41(1):8-13.

\section{Abstract \\ Keywords \\ - inflammatory bowel disease \\ - ocular manifestations}

Introduction The manifestations of inflammatory bowel disease (IBD) are not restricted to the gastrointestinal tract. Musculoskeletal conditions are considered the most common extraintestinal manifestations, followed by mucocutaneous and ocular diseases. Many general practitioners are unaware of the variety and severity of the ocular affection in IBD patients.

Objective To assess the prevalence of extraintestinal manifestations in IBD patients at Kafrelsheikh governorate, and to evaluate the different ocular manifestations and their relationship to the severity of the disease.

Methods A cross-sectional study evaluating 120 patients treated at the Kafrelsheikh University Hospital. The diagnosis of IBD was made between December 2018 and December 2019 through clinical, endoscopic and histopathological examinations. All patients were assessed for any extraintestinal manifestation or evidence of ocular affection through slit-lamp examinations, tonometry, visual acuity, and indirect ophthalmoscopy.

Results The mean age of the sample was $35.5 \pm 13.3$ years. In total, 52 (43.3\%) patients were male and 68 (56.7\%) were female. Ocular manifestations represent $22.5 \%$ of extraintestinal manifestations. The most common ocular findings were conjunctivitis $(25.8 \%)$ and anterior uveitis $(10.8 \%)$, followed by scleritis $(9.2 \%)$ and received

April 7, 2020

accepted

August 8, 2020
DOI https://doi.org/

$10.1055 / \mathrm{s}-0041-1724056$. ISSN 2237-9363.

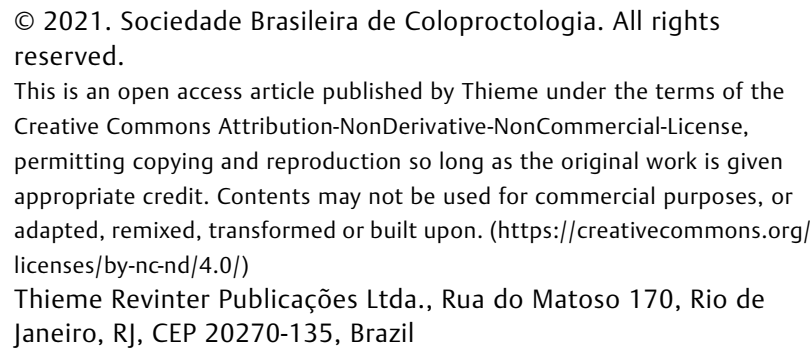

(c) 2021. Sociedade Brasileira de Coloproctologia. All rights reserved.

This is an open access article published by Thieme under the terms of the Creative Commons Attribution-NonDerivative-NonCommercial-License, permitting copying and reproduction so long as the original work is given appropriate credit. Contents may not be used for commercial purposes, or adapted, remixed, transformed or built upon. (https://creativecommons.org/ licenses/by-nc-nd/4.0/)

Thieme Revinter Publicações Ltda., Rua do Matoso 170, Rio de Janeiro, RJ, CEP 20270-135, Brazil 


\section{Resumo}

\author{
Palavras-chave \\ - doença inflamatória \\ intestinal \\ - manifestações \\ oculares
}

cataract (8.3\%). Other extraintestinal manifestations were observed in 41 (34.1\%) 29 (29.9\%) of ulcerative colitis cases, and 12 (52\%) of Crohn disease cases. There was no statistically significant difference in the presence of ocular involvement in relation to the two types of IBD included in the Montreal classification.

Conclusion Ocular manifestations in cases of IBD are common and usually nonspecific in presentation. The severity of the IBD does not reflect the severity of the ocular affection.

Introdução As manifestações da doença inflamatória intestinal (DII) não se restringem ao trato gastrointestinal. Distúrbios musculoesqueléticos são considerados as manifestações extraintestinais mais comuns, seguidos de doenças oculares e mucocutâneas. Muitos clínicos gerais desconhecem a variedade e a severidade das afecções oculares em casos de DII.

Objetivo Determinar a prevalência das manifestações extraintestinais em pacientes com DII na província de Kafrelsheikh, no Egito, e avaliar as diferentes manifestações oculares e sua relação com a gravidade da doença.

Métodos Um estudo transversal que avaliou 120 pacientes tratados no Kafrelsheikh University Hospital. O diagnóstico de DII foi feito entre dezembro de 2018 e dezembro de 2019 por meio de exames clínicos, endoscópicos e histopatológicos. Por meio de exames de lâmpada de fenda, tonometria, acuidade visual, e oftalmoscopia indireta, todos os pacientes foram avaliados para se determinar a ocorrência de quaisquer manifestações extraintestinais ou afeç̧ões oculares.

Resultados A média de idade da amostra foi de 35,5 $\pm 13,3$ anos. No total, 52 (43,3\%) pacientes com DIl eram do sexo masculino, e 68 (56,7\%), do sexo feminino. As manifestações oculares representaram $\sim 22,5 \%$ das manifestações extraintestinais. Os achados oculares mais comuns foram conjuntivite $(25,8 \%)$ e uveíte anterior $(10,8 \%)$, seguidas de esclerite $(9,2 \%)$ e catarata $(8,3 \%)$. Outras manifestações extraintestinais foram observadas em $41(34,1 \%)$ pacientes, entre elas, $29,9 \%$ de casos de colite ulcerativa, e $52 \%$ de casos de doença de Crohn. Não houve diferença estatisticamente significativa na presença de envolvimento ocular com relação aos dois tipos de DII descritos na classificação de Montreal.

Conclusão As manifestações oculares em pacientes de DIl são comuns e, geralmente, não específicas em termos de apresentação. A gravidade da DII não reflete a gravidade da afecção ocular.

\section{Introduction}

The manifestations of the two types of inflammatory bowel disease (IBD), Crohn disease and ulcerative colitis, are not restricted to the gastrointestinal tract. Unfortunately, the patients may develop various extraintestinal manifestations (EIMs), ${ }^{1}$ whose onset may be at any time during the course of the disease, and musculoskeletal conditions are considered one of the most common, followed by mucocutaneous and ophthalmic diseases., ${ }^{2,3}$ But other organs, such as the skin, the liver, and the kidney, as well as the endocrine systems, can be involved, leading to significant morbidity and representing a challenge to the clinicians who manage those patients. In fact, many general practitioners are unaware of the variety and severity of ocular affections in cases of IBD. These ocular complications are usually of an inflammatory origin, 4,5 and they are classified into primary, secondary, and coincidental. Primary complications are temporally related to IBD exacerbations, and usually respond to anti-inflammatory drugs. These include keratopathy, episcleritis, and scleritis. Secondary complications, such as scleromalacia due to scleritis, and dry eye due to hypovitaminosis A following gut resection, occur as a result of the primary complications. Coincidental complications commonly occur in the general population, and cannot be correlated to IBD alone. These include conjunctivitis, recurrent corneal ulcer, and corneal erosions. ${ }^{6}$ The goal of the present prospective randomized clinical study was to assess the prevalence of EIMs among IBD patients at the Kafrelsheikh governorate, and to evaluate the different ocular affections and their relationship to the severity of the disease. 


\section{Patients and Methods}

\section{Participants}

The present is a cross-sectional study performed on 120 patients who had been previously diagnosed with IBD at the Kafrelsheikh University Hospital from December 2018 to December 2019. We included patients previously diagnosed with IBD by endoscopy and histopathological examinations, and excluded patients with previous chronic eye disease that was not related to IBD, as well as those who refused the follow-up evaluation.

\section{Baseline Evaluation}

All patients were required to provide a detailed medical history, and they underwent a complete clinical examination for any EIMs (especially ocular manifestations), associated autoimmune diseases, and endocrinological diseases or evidences thereof. Stool samples were taken and tested regarding the level of calprotectin, and the eye examination consisted of the slit-lamp exam, tonometry, visual acuity, and indirect ophthalmoscopy.

\section{Ethics and Consent}

The present study was approved by the institutional Ethics Committee, and permission was obtained from all department heads, who were assured that confidentiality would be maintained and ethical principles would be followed. Before the beginning of the study, a background about it and the reason for it were explained, and the targeted population were encouraged to participate without any undue pressure, and written informed consent was be obtained.

\section{Statistical Analyses}

Sorting and the analysis of the data were performed the using Statistical Package for Social Sciences (SPSS, IBM Corp., Armonk, NY, US), version 21. In this study the qualitative variables were prescribed using number and percent, Chisquare test was used for analysis (Mont Carlo exact test and Fishers exact test were used as alternatives for Chi-square test if there were many small expected values). Numerical variables were expressed as mean \pm standard deviation or median (IQR). The independent sample $t$-test (for normal distributed data) or Mann-Whitney U-test (for non-normal distributed data) were used for comparison between groups. $P$ value $(\leq 0.05)$ was adopted as the level of significance.

\section{Results}

A total of 120 patients with IBD were enrolled in the present study.

- Table 1 shows the demographics of the sample, which was composed of 52 (43.3\%) male patients and 68 (56.7\%) were female patients whose mean age was $35.5 \pm 13.3$ years.

Ocular affections represent $\sim 22.5 \%$ of EIMs; other EIMs were observed in 41 (34.1\%) patients in the sample: in $29.9 \%$ of those with ulcerative colitis, and in $52 \%$ of those with Crohn disease (-Table 2). The incidence of EIMs such as associated systemic lupus erythematosus (SLE), hypothyroidism and mullerin agenesis did not exceed $0.8 \%$ (one case for each diagnosis).

There were no statistically significant differences in the presence of ocular involvement in relation to the Montreal classification of two types of IBD (ulcerative colitis: $p=0.269$; Crohn disease: $p=1.00 ;$ - Table 3).

- Table 4 shows a comparison of the median level of calprotectin in relation to the presence of ocular involvement in the two types of IBD, with no statistically significant difference (ulcerative colitis: $p=0.562$; Crohn disease: $p=0.968)$.

The most common ocular findings were conjunctivitis: in 31 cases (25.8\%), anterior uveitis in 13(10.8\%), scleritis in 11 (9.2\%), cataract in $10(8.3 \%)$, posterior uveitis in $4(3.45 \%)$,

Table 1 Demographic characteristics of patients with inflammatory bowel disease who underwent an ophthalmologic examination

\begin{tabular}{|l|l|l|l|l|}
\hline Characteristic & Total $(\boldsymbol{n}=\mathbf{1 2 0})$ & Ulcerative colitis $(\boldsymbol{n}=\mathbf{9 7})$ & Crohn disease $(\boldsymbol{n}=\mathbf{2 3})$ & $\mathbf{p}$-value \\
\hline $\begin{array}{l}\text { Age (years) mean } \pm \\
\text { standard deviation }\end{array}$ & $35.5 \pm 13.3$ & $36.3 \pm 13.8$ & $32 \pm 10.8$ & .107 \\
\hline Gender $-\boldsymbol{n}(\%)$ & & & & $.020^{*}$ \\
\hline Male & $52(43.3)$ & $47(48.5)$ & $5(21.7)$ & \\
\hline Female & $68(56.7)$ & $50(51.5)$ & $18(78.3)$ & \\
\hline $\begin{array}{l}\text { Other extraintestinal } \\
\text { manifestations }-n(\%)\end{array}$ & & & & .542 \\
\hline Hypothyroidism & $1(0.8)$ & $1(1.0)$ & $0(0.0)$ & \\
\hline Mullerin agenesis & $1(0.8)$ & $0(0.0)$ & $1(4.3)$ & \\
\hline $\begin{array}{c}\text { Systemic lupus } \\
\text { erythematosus }\end{array}$ & $1(0.8)$ & $1(1.0)$ & $0(0.0)$ & .514 \\
\hline $\begin{array}{l}\text { Patients with ocular } \\
\text { manifestations - } n \text { (\%) }\end{array}$ & $27(22.5)$ & $23(23.7)$ & $4(17.4)$ & \\
\hline
\end{tabular}

Note: *Statistically significant value. 
Table 2 Distribution of extraintestinal manifestations

\begin{tabular}{|l|l|l|l|l|l|l|l|l|l|}
\hline & $\begin{array}{l}\text { Axial } \\
\text { arthralgia }\end{array}$ & $\begin{array}{l}\text { Cut. } \\
\text { Fistula }\end{array}$ & $\begin{array}{l}\text { Erythema } \\
\text { nodosum }\end{array}$ & $\begin{array}{l}\text { Musculo- } \\
\text { skeletal }\end{array}$ & $\begin{array}{l}\text { Perianal } \\
\text { fistula }\end{array}$ & PSC & Pyoderma & $\begin{array}{l}\text { Musculoskeletal } \\
\text { pyoderma }\end{array}$ & $\begin{array}{l}\text { Renal } \\
\text { stone }\end{array}$ \\
\hline $\begin{array}{l}\text { Ulcerative } \\
\text { colitis - n (\%) }\end{array}$ & $0(0.0 \%)$ & $0(0.0 \%)$ & $9(9.3 \%)$ & $7(7.2 \%)$ & $0(0.0 \%)$ & $4(4.1 \%)$ & $4(4.1 \%)$ & $0(0.0 \%)$ & $5(5.2 \%)$ \\
\hline $\begin{array}{l}\text { Crohn } \\
\text { disease - n (\%) }\end{array}$ & $1(4.3 \%)$ & $3(13.0 \%)$ & $2(8.7 \%)$ & $3(13.0 \%)$ & $1(4.3 \%)$ & $0(0.0 \%)$ & $0(0.0 \%)$ & $2(8.7 \%)$ & $0(0.0 \%)$ \\
\hline Total - n (\%) & $1(0.8 \%)$ & $3(2.5 \%)$ & $11(9.2 \%)$ & $10(8.3 \%)$ & $1(0.8 \%)$ & $4(3.3 \%)$ & $4(3.3 \%)$ & $2(1.7 \%)$ & $5(4.2 \%)$ \\
\hline
\end{tabular}

Table 3 Incidence of ocular involvement in cases of ulcerative colitis and Crohn disease

\begin{tabular}{|l|l|l|l|}
\hline & & Ocular involvement $-\mathrm{n}(\%)$ & $p$-value \\
\hline Ulcerative colitis & E1 $(n=26)$ & $9(34.6)$ & .269 \\
\hline & E2 $(n=46)$ & $10(21.7)$ \\
\hline & E3 $(n=25)$ & $4(16.0)$ \\
\hline & Total $(n=97)$ & $23(23.7)$ & 1.00 \\
\hline & A1L3B1 $(n=13)$ & $2(15.4)$ & $2(20.0)$ \\
\hline & A2L3B2 $(n=10)$ & $4(17.4)$ & \\
\hline
\end{tabular}

reviations: E1, extension limited to the rectum; E2, Left sided UC (distal UC); E3, Extensive UC; A1, age of diagnosis = 16 years or younger; A2 and A3, age of diagnosis at 17-40 years and >40 years, respectively; L3, ileocolonic; B1, non-stricturing, non-penetrating; B2, stricturing.

Table 4 Median level of calprotectin in relation to the presence or absence of ocular involvement

\begin{tabular}{|l|l|l|}
\hline & $\begin{array}{l}\text { Level of calprotectin } \\
\text { Median (IQR) }\end{array}$ & $p$-value \\
\hline Ulcerative colitis & $\begin{array}{l}\text { With ocular involvement: } 800(528.50-997.25) ; \\
\text { without ocular involvement: } 685(500-913)\end{array}$ & 0.458 \\
\hline Crohn disease & $\begin{array}{l}\text { With ocular involvement: } 750(133.25-2462.50) ; \\
\text { without ocular involvement: } 1000(320-1500)\end{array}$ & 0.785 \\
\hline
\end{tabular}

\section{Ophthalmologic Manifestations of IBD Patients}

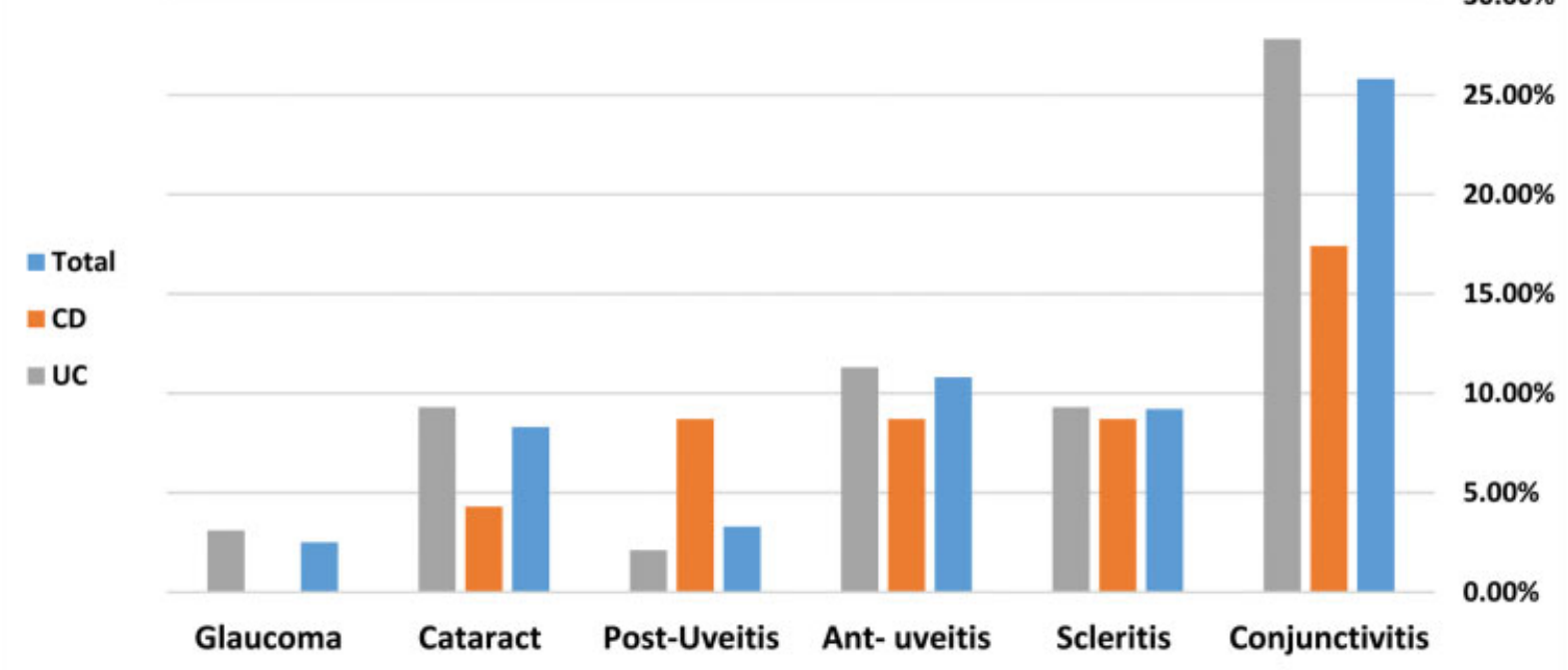

Fig. 1 Ocular manifestation on patient with inflammatory bowel disease. 


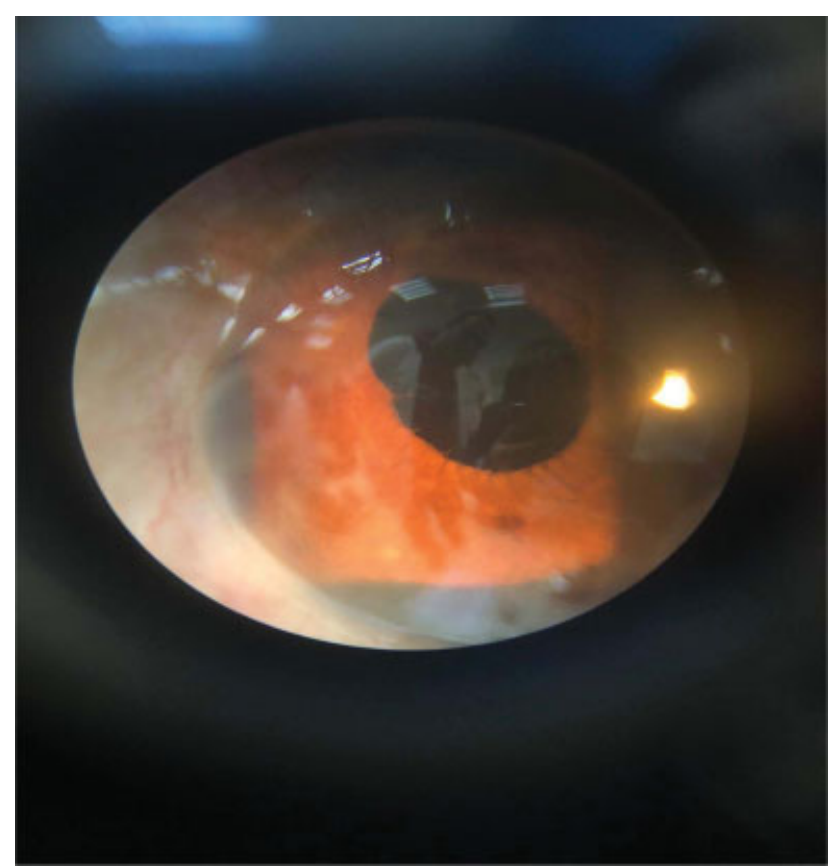

Fig. 2 Recurrent anterior uveitis with secondary intraocular lens after complicated cataract.

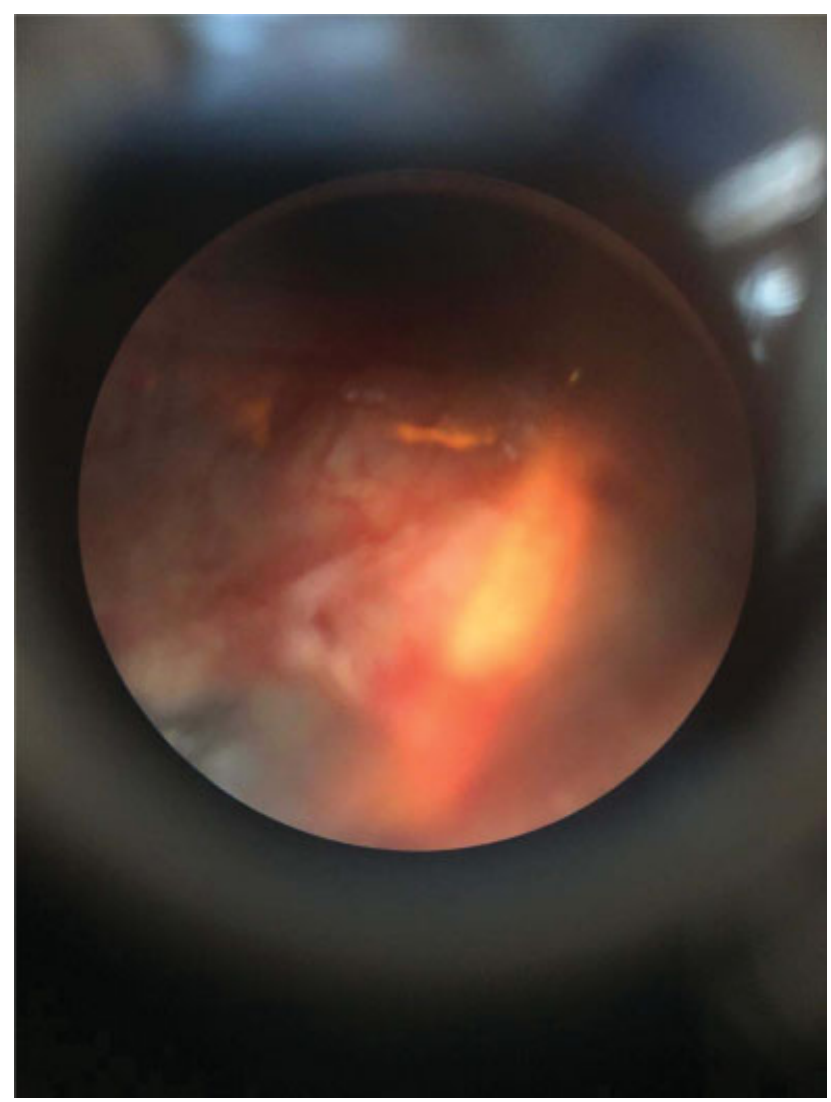

Fig. 3 Conjunctivitis, scleritis and episcleritis.

and 3 cases in glaucoma (2.5\%), with no statistically significant difference between ulcerative colitis and Crohn disease (-Fig. 1-3).

\section{Discussion}

The ocular complications of IBD are still a problematic issue not only in Egypt; they are an ongoing worldwide challenge, due to their early onset and silent progressive course. In the present study, EIMs were in 41 (34.1\%) patients: in 29.9\% of those with ulcerative colitis, and in $52 \%$ of those with Crohn disease. Peyrin-Biroulet et $\mathrm{al}^{4}$ stated that the prevalence of EIMs is variable, and it ranges between $12 \%$ and $35 \%$ in cases of ulcerative colitis, and between $25 \%$ and $70 \%$ in cases of Crohn disease. In the present study, dermatological and musculoskeletal manifestations are the second most common after ocular affections, a result which is in line with the one reported by the guidelines of the Brazilian Study Group of Inflammatory Bowel Diseases. ${ }^{7}$

The eyes are involved in about $22.5 \%$ of all EIMs; nevertheless Felekis et al., ${ }^{8}$ in a prospective study, performed complete eye examinations in 60 IBD patients, and found a frequency of $43 \%$ of ocular EIMs. However, this higher percentage could be due to the inclusion of patients with previous chronic eye diseases.

In their study, Akpek et al. ${ }^{6}$ stated that ocular involvement does not always coincide with an active intestinal flare. In the present study, we observed no statistically significant differences in the presence of ocular involvement in relation to the Montreal classification of two types of IBD (ulcerative colitis: $p=0.269$; Crohn disease: $p=1.00$ ), or regarding the mean level of calprotectin.

Different incidence rates of ocular EIMs have been reported in previous studies ${ }^{8,9}$; in the present study, the most common ocular findings were conjunctivitis: in 31 cases (25.8\%), anterior uveitis in $13(10.8 \%)$, scleritis in $11(9.2 \%)$, cataract in 10 (8.3\%), posterior uveitis in 4 (3.45\%), and 3 cases in glaucoma (2.5\%) with no statistically significant differences between ulcerative colitis and Crohn disease. In another study, Petrelli et al., ${ }^{9}$ stated that the prevalence of ocular complications observed in cases of IBD varies among studies (uveitis: $0.0001 \%$ to $0.01 \%$; conjunctivitis: $0.1 \%$ to $7 \%$; blepharitis: $3.5 \%$ to $15 \%$; and cataract: $0.3 \%$ to $15 \%$ ).

The present study has several limitations, such as the relatively small sample size and no addressing of correlation between laboratory findings and the severity of eye affection.

\section{Conclusion}

Ocular manifestations among IBD patients are common and usually nonspecific in their presentation; therefore, eye examinations should be a part of the routine assessment and follow-up of IBD patients. The early diagnosis and management of ocular EIMs may prevent serious complications that could be associated with significant visual deterioration. In addition, the general practitioner and gastroenterologist should be aware of the frequency and variety of EIMs in general, such as uveitis and sclerites, for they might precede a diagnosis of ulcerative colitis or Crohn disease.

\section{Conflict of Interests}

The authors have no conflict of interests to declare. 


\section{References}

1 Ghanchi FD, Rembacken BJ. Inflammatory bowel disease and the eye. Surv Ophthalmol 2003;48(06):663-676

2 Ruiz Serrato A, Marín García D, Guerrero León MA, et al. [Palpebral ptosis, a rare ocular manifestation of Crohn's disease]. Arch Soc Esp Oftalmol 2013;88(08):323-326[PMID:23886366 DOI: 10.1016/j. oftal.2011.09.024]

3 Hopkins DJ, Horan E, Burton IL, Clamp SE, de Dombal FT, Goligher JC. Ocular disorders in a series of 332 patients with Crohn's disease. $\mathrm{Br} \mathrm{J}$ Ophthalmol 1974;58(08): 732-737

4 Peyrin-Biroulet L, Van Assche G, Gómez-Ulloa D, et al. Systematic Review of Tumor Necrosis Factor Antagonists in Extraintestinal Manifestations in Inflammatory Bowel Disease. Clin Gastroenterol Hepatol 2017;15(01):25-36.e27[PMID: 27392760 DOI: 10.1016/ j. cgh.2016.06.025]
5 Goudet P, Dozois RR, Kelly KA, Ilstrup DM, Phillips SF. Characteristics and evolution of extraintestinal manifestations associated with ulcerative colitis after proctocolectomy. Dig Surg 2001;18 (01):51-55[PMID: 11244260 DOI: 10.1159/000050097]

6 Akpek EK, Thorne JE, Qazi FA, Do DV, Jabs DA. Evaluation of patients with scleritis for systemic disease. Ophthalmology 2004;111(03): 501-506

7 Brazilian Study Group of Inflammatory Bowel Diseases. Consensus guidelines for the management of inflammatory bowel disease. Arq Gastroenterol 2010;47(03):313-325

8 Felekis T, Katsanos K, Kitsanou M, et al. Spectrum and frequency of ophthalmologic manifestations in patients with inflammatory bowel disease: a prospective single-center study. Inflamm Bowel Dis 2009;15(01):29-34[PMID: 18626979 DOI: 10.1002/ibd.20584]

9 Petrelli EA, McKinley M, Troncale FJ. Ocular manifestations of inflammatory bowel disease. Ann Ophthalmol 1982;14(04):356-360 